\title{
Raising Cultural Awareness in EFL Classes
}

\section{Irene Mine}

\section{Utsunomiya University}

\section{Chieko Mimura}

Utsunomiya University

\section{Reference Data}

Mine, I., \& Mimura, C. (2021). Raising cultural awareness in EFL classes. In P. Clements, R. Derrah, \& P. Ferguson (Eds.), Communities of teachers \& learners. JALT. https://doi.org/10.37546/ JALTPCP2020-29

Teaching culture is essential in a language class, as language is an inseparable part of culture. Yet incorporating culture into an EFL class can give rise to challenges, such as indefinable target cultures, the creation of possible stereotypes, unforeseeable results, difficulties in assessment, and the elusive concept of culture itself. Accepting those challenges, culture can be incorporated into a language classroom not by explicitly introducing a specific culture, but by attempting to raise the students' cultural awareness. In this study we presented students with real-life stories of intercultural experiences in university English classes. The students' responses to reading prompts, class reflections, and interviews demonstrated the effectiveness of the teaching activity in raising cultural awareness. We also found that raising cultural awareness leads to a wider awareness of "unknowns." Our results suggest that teaching culture implicitly may be effective in raising the cultural awareness of students in a language class.

言語の授業において文化を教えることは必要不可欠である。言語は文化の一部であり切り離すことはできないからである。 しかし、EFL (外国語としての英語) の授業において文化を組み入れることは難しい。ターゲットとする文化が決められないこ と、ステレオタイプを生む可能性があること、結果が見えづらいこと、評価が困難であること、そして、文化の定義そのものの問 題である。これらの課題を受け入れ、特定の文化を明示的に指導するのではなく、学習者の文化的意識を高めることを目指し て文化を指導することが有効である。本研究では、大学の英語の授業で、教員の異文化体験の実話を教材とした。その結果、 教材への問いや、リフレクション及びインタビューから、異文化意識の向上が見られた。異文化意識はまた、「知らないことへ
の意識」というさらに深い意識へとつながつた。本研究は学習者の異文化意識向上のために文化を非明示的に指導する可能 性を示唆する。

he teaching and learning of languages involve more than linguistic processes (Kumaravadivelu, 2008). To communicate effectively with people from different cultures, a communicator must have knowledge about other cultures and skills in navigating between cultures (Byram, 1997). In an educational setting, a teacher seeking to incorporate culture in a language classroom must consider several questions. One of those questions is, "What is culture?" While culture has been defined in various ways, none of the definitions are conclusive (Baker, 2011). Culture, moreover, tends to be viewed as fixed, monolithic, geographical-based characteristics of people, customs, lifestyles, and societies-something which it is not. Another question is, "How is culture incorporated in language classrooms?" Difficulties arise in the selection of materials teaching methodology, and assessment.

Recognizing the difficulties and accepting the current limitations, we attempt in this study to incorporate culture in EFL classrooms in an English program of a national university in Japan. Our objective is to raise the cultural awareness of the students, and methodologically, we carefully consider how not to teach or perpetuate cultural stereotypes.

\section{What is Culture?}

Culture has been considered one of the most complex words for centuries (Williams, 1976). The word has appeared in many disciplines, and in connection with other concepts, such as globalization (Kumaravadivelu, 2008; Tomlinson, 1999), identity (Hall, 1997), language (Gee, 1993), and language teaching and learning (Atkinson, 1999). Scholars have taken on the difficult challenge of defining culture in different ways. However, as 
Kumaravadivelu (2008) argues, any definition of culture is seldom maintained. While culture "undoubtedly shapes the life of individuals, communities, and nations," he writes, it is also "vague" and "contentious" (p. 27). In the sense of creating and explaining rules and images of how human beings are, culture is similar to discourse, or, as Kramsch (1998) defines it, as a "discourse community" (p. 127). Like discourse, a critical dimension of culture is that culture is not fixed, but it is a "process that both includes and excludes, always entails the exercise of power and control" (Kramsch, 1998, p. 8).

\section{Culture and Language Teaching/Learning}

Whatever the definition of culture is, language is a component of culture (Arabski \& Wojtaszk, 2011). As Hesar, Konka, and Zarfsaz (2012) maintain, "our culture affects the way we make sentences and the way we interpret the meaning" (p. 70). As language learning nurtures cultural understanding, culture has always been an integral part of language education (Kumaravadivelu, 2008). Cultural knowledge, skills, and attitudes are important for effective communication, and fostering Intercultural Communicative Competence (ICC: Byrum, 1997) has been a widely shared aim in second language classrooms.

In fact, culture has been adopted as one of the crucial components to assess the development of language in Western countries, such as the $5 \mathrm{Cs}$ (Communication, Culture, Connections, Comparisons, and Communities) in the U.S. (The National Standards for Foreign Language Education Project, 1996, in Kumaravadivelu, 2008, p. 24), and ICC encompassed in CEFR (Common European Framework of Reference; Council of Europe, 2001) in Europe. In Japan, on the other hand, while the goal setting of language learning is referenced by CEFR (MEXT, 2018), culture has not been clearly included as a major component of English education in Japan's latest curriculum guidelines by MEXT Course of Study. This may be unsurprising, as language learners in Japan seldom face multicultural communication in their daily lives.

\section{Difficulties in Teaching Culture}

Although teaching culture is crucial in language teaching and learning, several challenges have been discussed. First, in the concept of English as a Lingua Franca (ELF) or English as an International Language (EIL), "particular linguistic codes are not inherently linked to particular cultures, or linguacultures" (Baker, 2011, p. 89). This suggests that target cultures are either indefinable or require no definition. Selecting materials can be difficult when there are no traditions of providing cultural context in a curriculum.
Second, teaching culture can create stereotypical images of other countries, as the images and attitudes the teachers have towards particular cultures may be reflected in their teaching. Not only teachers, but also materials, create static images of particular cultures (Matsuura, Miyazaki, \& Fukushima, 2012). It is also argued that the process by which an awareness of culture emerges in learners is unforeseen and unmeasurable (Matsuura, Miyazaki, \& Fukushima, 2012). On the other hand, while many materials inevitably include stereotypes, those that do can be used to "deconstruct" and "address misconceptions" (Lopez-Rocha, 2016, p. 108). If such materials are to be introduced and used to those ends, however, the language teacher requires the knowledge and skills to properly deal with the responses of the students regarding cultural stereotypes of the target language (Aufa, 2013).

The third point of difficulty is related to the purpose of teaching culture and the issue of whether culture can be taught. McKay (2002) argues that cultural information provided solely in the classroom is insufficient to spark insight on interacting with people from other cultures. This third point related to purpose leads to a fourth point, namely, difficulty in the assessment. Byrum (1977) formulates the assessment objectives of ICC in terms of knowledge, attitudes, skills in interpreting and relating, and critical cultural awareness. A list of these objectives has been adopted in different modalities (e.g., Erdorff \& Arasarantnam-Smith, 2017; Ottoson, 2016), and several researchers have devised tasks and scales for measuring ICC (Matsumoto, 2013; Skopinskaya, 2009). The efficacy and validity of the ICC objectives have yet to be proved.

Last, and more fundamentally, language educators and researchers should reconsider the conceptualization of culture in the TESOL field. According to Atkinson (1999), the field has absorbed a "received view" of culture (Atkinson, 1999), as "geographically (and quite often nationally) distinct entities, as relatively unchanging and homogenous, and as allencompassing systems of rules or norms that substantially determine personal behavior" (p. 626). Based on the notions that all humans are individual, that individuality is cultural, and that culture is multiple, complex, and changing, the static, culture-as-nationality conceptualization of culture should be reconsidered in TESOL (Atkinson, 1999).

\section{Accepting the Difficulties in Teaching Culture}

We have reviewed the difficulties in conceptualizing culture as well as in incorporating culture in language teaching. Accepting those difficulties, especially the fact that our teaching may not reach beyond the above-mentioned "received view of culture," we try to develop materials and methods to incorporate culture in the language classroom for 
the purpose of raising the students' cultural awareness. Particularly, in order to avoid a fixed dichotomy between Western culture and Eastern culture, or any stereotypical images of culture, we develop an implicit way to present cultural materials and elicit the students' free reflections. The questions we seek to answer in this research through the materials we developed are: First, how will the implicit teaching of culture increase the students' cultural understanding and awareness? Second, how will the students' images and perceptions of other countries change through the implicit teaching of culture?

Third, how will the students reflect upon the intercultural experiences of the teachers?

\section{Participants and Settings}

\section{Method}

The authors' school is a national university located in eastern Japan, and all of its first- and second-year students are enrolled in a coordinated English program. It seeks to improve students' overall communication abilities in English using a balanced, integrated approach incorporating the four skills of speaking, reading, writing, and listening, while cultivating the knowledge, skills, and attitudes necessary for further academic study and active participation in the global workforce. From the program side, it is crucial to incorporate cultural aspects in teaching in order to help students develop skills to engage in global communication.

In reality, most of the students have little intercultural experience in their daily lives and are unlikely to extensively interact with other cultures in the future. The goal of studying culture is to attain heightened awareness about the differences, as well as the similarities, between their own lifestyles, identities, values, norms, and other aspects of their lives. The university also promotes activities for the United Nation's 17 Sustainable Development Goals (SDGs), and in their major faculties, the students participate in various related activities, both in their local communities and internationally. Studying culture should connect the language learning to their majors and provide an enduring motivation to study the English language.

Out of 950 1st-year students in five different majors (Agriculture, Engineering, Regional Design, International Studies, and Education), 600 intermediate-level students with the TOEIC score of 300 to 500 participated in this research. Among the five levels that the English program offers, the 600 students all fell between level 1 and level 3 .

This was a convenience sample as the researchers had intermediate-level students for the semester. The classes were conducted online using C-learning, which is an online education support system that connects teachers and students virtually. After the classes, a series of short 30-minute interviews were conducted with a total of 10 volunteer students, five males and females with the age of 18 to 19, through Zoom. They were all intermediate-level students, one majoring in Agriculture, two in Engineering, four in International Studies, and three in Education. We have obtained informed consent and institutional clearance.

\section{Procedure}

The culture classes were conducted as part of English classes twice a semester, nonconsecutively. In each class, the students read stories recounting the teachers' real-life experiences in intercultural communication (Appendix A). Students read three stories in each class. In the first class, the students began by reviewing a list of words and phrases used in the reading materials. Next, they read one of the stories, checked their understanding of the story and answered reading prompts (Appendix B). We did not specify the language for the responses. They then repeated the same flow for the second and third stories. Near the end of the class, they wrote their reflections on the stories.

The same structured lesson was conducted for the second class, but at the end the students were given a questionnaire regarding both that class and the class before (Appendix C). Finally, the volunteer students were interviewed (Appendix D). Then analysis was made on the students' responses to the reading prompts, the students' reflections, and the interview (Figure 1). From the reading prompts, students' comments were selected if they sounded stereotypical or if comments showed that unintended messages were delivered from the reading material. We considered comments were stereotypical when the comments focused on the tendency of a country or comments stated the character of a country as if there were no diversity within it. We considered unintended messages were delivered when the comments didn't align with the concepts of the stories. For class reflection, we sorted out students' comments into five categories that are generated from the comments. For the interview, we have sorted the comments by those who had little or no intercultural experience and comments by those who had some intercultural experiences in the past. As we did not collect the data on how much the students who participated in the classes had intercultural communication experiences, we focused on this aspect in the interview. 
JALT2020

COMMUNITIES OF
TEACHERS \& LEARNERS

Figure 1

Process of the Classes and Research

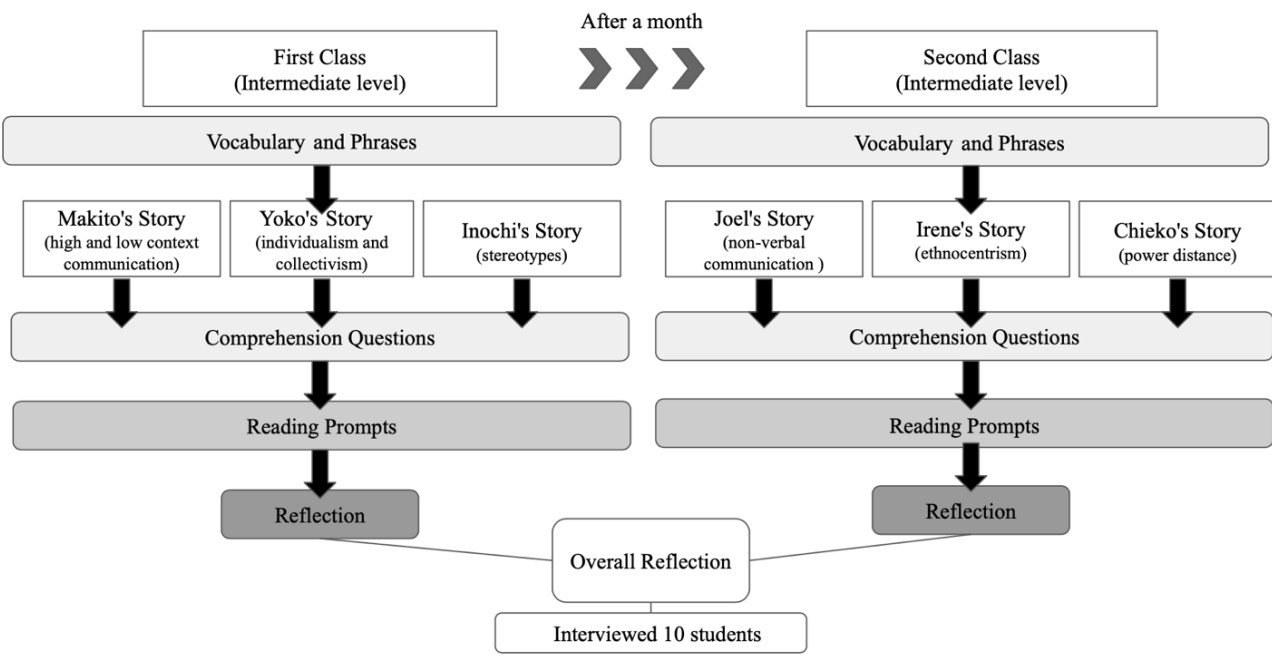

\section{Reading Materials}

The reading materials, real-life stories written by the authors and their colleagues, were based on six concepts: 1) high- and low-context communication, 2) individualism vs. collectivism, 3) stereotypes, 4) non-verbal communication, 5) ethnocentrism, and 6) power distance (Appendix A). Two of the concepts, power distance and individualism vs. collectivism, were chosen from Greet Hofstede's model (2011) of six dimensions of national cultures, in consideration of the students' backgrounds. The other four concepts, non-verbal communication, high and low context communication, stereotypes, and ethnocentrism were chosen from Ting-Toomey and Chung (2011).

\section{How We Taught Implicitly}

Our main tactic in teaching implicitly was the use of real-life stories. Students received direct input of the life experience of others by reading the materials and reflecting upon them to themselves. We omitted the names of the concepts and dimensions in the reading materials, as our goal was not to have the students learn the concepts, which could have also resulted in explicit teaching.
There were several minor tactics, such as not introducing the classes as "cultura learning classes" but instead using the title, "teachers' stories." We also brought the topic into focus at the beginning of the class by pointing out how it could be more effective to learn not only through our own experiences, but also from other people's experiences. In addition, we avoided the use of any controlled questions for the reading prompts, as we wanted the students to learn from their own reflections.

\section{Data Analysis}

Our research examines our students' thoughts and reflections about the cross-cultural experiences of their teachers. We attempted to triangulate the data by repeatedly prompting the students to voice their thoughts by different questions and conducting volunteer-based interviews. We sorted the students' comments by the categories generated from them, applying no framework for analysis.

\section{Reading Prompts}

\section{Findings and Discussion}

Students who participated in the class were asked to answer the set of reading prompts after they read each story (Appendix B). The students' responses to these reading prompts were used to see whether the reading materials gave them stereotypical images of other countries and whether the students understood the messages that we intended to convey in the stories.

While it was difficult to draw a line to demarcate what was stereotypical, we detected several stereotypical comments that could impart negative feelings to persons from the cultures described. Some of the comments from the students also centered around stereotypes about their own culture. While most of the students understood the intended messages, some had different interpretations. Some of the students' comments are listed in Appendix E, 1.

\section{Class Reflection}

In the class reflection stage, students who participated in the class were asked to reflect freely on the lesson. Most of the comments indicated positive outcomes. Many students commented that they had come to realize the importance of knowing, being aware, and being understanding of other cultures. Some found learning about other cultures and intercultural communication interesting and realized that differences also appear even 
within one's own culture. A few commented that they felt regretful about their negative attitudes or judgmental thoughts in the past. Some described negative reactions, such as feelings of inferiority next to other cultures. Some of the students' comments in the stage of class reflection are in Appendix E, 2.

\section{Overall Reflection}

At the end of the second class, the students were asked again to fill out a questionnaire, to survey their thoughts on the past two lessons (Appendix C). When asked, "Were there any changes in your interest towards intercultural communication?" Approximately $67 \%$ of the students answered "yes," 30\% "no," and 3\% did not answer. All of the comments who answered "yes" can be grouped into one of the following categories: "gained interest," "gained awareness," "gained a deeper understanding," "changed my way of thinking," and "worried about communicating interculturally." Thirty percent of the students answered "no" to the question, and most of them commented that they had already been interested in intercultural communication before the class began. This means that the class content did not particularly affect their interest.

When asked, "What did you learn the most through these classes?" the students gave various answers. Some described cultural differences, while others mentioned the importance of knowing the differences, and difficulties in understanding the differences without actually experiencing them. Some of the students' comments in the stage of overall reflection are in Appendix E, 3.

\section{Interview}

Through the interviews, we mainly learned how the effects of the lessons varied according to the students' previous intercultural experience. For the students who had little or no previous intercultural experience, the classes were an opportunity to connect the learning of English with culture, to think about their relationships with other people (friends, teachers, etc.), to examine their own prejudices, and to gain motivation to study English. For the students who had some intercultural experience, the classes were an opportunity to revisit their memories of their past intercultural communication. Some of these latter students voiced critical views. Refer to Appendix E, 4 for some of the comments made by the interviewees.

\section{Effectiveness of Implicit Teaching}

Though it is not a significant impact, implicit teaching increased students' cultural understanding and awareness at a deeper level. Students' comments reflected their realization of their ignorance towards people of other cultures as well as their learning about how people's words and actions depend on their background and how cultural differences appear at the communicative level. This answers our first research question of how the implicit teaching of culture will increase the students' cultural understanding awareness. Implicit teaching stimulated the students to think about cultural differences not only on the country basis but also the individual basis, which also led them to think about their unconscious images and perceptions of people of other cultures that they gained through limited information and their lack of knowledge and exposure. However, the profound meaning of teaching implicitly instead of explicitly in this aspect is yet to be discovered. This answers our second research question of how the students' images and perception of other countries will change through the implicit teaching of culture.

\section{Teacher-Generated Materials}

We found that teacher-generated materials are a powerful aid to motivate students to actively participate (Davies, 2002). Offering them real-life stories of someone who they are in contact with, was a good way to lead them to insights into highly authentic intercultural encounters which is not just someone else's business but something that can occur to them. From students' comments, we noticed that students learned that even teachers who seem to have no problems communicating in English also have experiences of struggles in communicating with people from other countries. We also noticed that this gave students an idea of how having good English skills does not necessarily lead to a good intercultural communication skill. It increased the students' feeling of a need to learn and be aware of the culture and gave them a chance to recognize how an awareness of cultural differences makes intercultural communication less stressful but more successful. This answers our third research question of how the students will reflect upon the intercultural experience of the teachers.

\section{Awareness of the Unknowns}

The students' comments also demonstrated how cultural awareness can lead students to an even greater awareness, that is, an awareness of the unknowns. Moving beyond thoughts about cultural awareness, many students seemed to gain such an awareness of the unknowns. Their comments reflected a newfound recognition of many things that 
they had not known, such as what others may be going through or how their actions stem from their unique individual life experiences. We could say that cultural awareness is in many ways the same as an awareness of the unknowns. Hence, by being aware of the unknowns, students can foster their own awareness of cultural differences because culture itself is largely unknown. Some students, moreover, individually figured out that the stories applied not just to intercultural communication situations, but also monocultural communication, even within their families and circles of friends. Teaching implicitly by letting students read authentic intercultural communication stories elicited critical thinking and self-reflection, which led many students to an awareness of the unknowns and to the recognition of differences within a culture. While, in this sense, we could say that some comments reflected stereotypical thinking, the lessons did not unduly create stereotypical images of other countries.

\section{Stereotypes and Negative Reactions}

Difficulties arise, however, in exactly where to draw the line between what is stereotypical and what is not. We could not be certain whether some comments were stereotypical or just simple statements comparing one culture to another in the manner crucially necessary to gain knowledge about other countries and cultural awareness. Regardless, a stereotype can be taken as a part of the learning process, and as something not wholly negative when students have the chance to continue the learning process. Similar things can be said of the negative reactions of the students, such as their feelings of anxiety about communicating with people from other cultures, or feelings of inferiority next to other cultures. Such negative reactions could be another sign of increased cultural awareness that can be either kept as part of the learning process or followed up by the teacher to unburden the students of their negative feelings.

\section{Limitation of the Study}

This research has its limitations under the period of world pandemic where online classes were obligatory at the author's university and the result might have made a difference if teaching had been done face-to-face. Students were unable to have an intercultural experience with people from outside of Japan; therefore, it may have been hard for some students to apply their learnings and keep up the motivation after the classes. While we hope the students will carry on their learning and awareness for culture in the future, this research is limited to finding whether the students' cultural awareness increased right after the classes. Lastly, it should be noted that we are regretful for not asking further from those who answered "no" to the reflection question, "Were there any changes in your interest towards intercultural communication?", because their reasons would have been a good source of findings of this study. This is a qualitative study, and no generalization or fixed truth has been found.

\section{Conclusion and Implication}

Through the analysis of students' comments, we conclude that the classes stimulated students' cultural awareness on the whole. The implicit teaching raised not only the students' cultural awareness but also their awareness of unknowns. Through the realization of their unknowns of others, students recognized diversity within a culture, and this made it possible to teach culture without unduly creating stereotypical images of other countries. Further, the use of authentic, real-life stories of teachers created a sense of closeness with the teachers for the students, by learning that even people with high-level English skills have troubles in intercultural communication. This emphasized the importance of learning and being aware of other cultures.

Now, we are left with a question of how exactly of a difference it will make in students' learning and awareness if culture is taught explicitly with a significant teacher intervention and controlled discussion questions, adding stereotypical and intense content materials. This research still has an extensive capacity to be enhanced in the direction of material development. Raising cultural awareness is a lengthy process, and cultural awareness is certainly difficult to measure. While the road to cultural competency is a long one, and a few lessons on cultural awareness will only take one so far, awareness can be a start for all that follows.

\section{Bio Data}

Irene Mine, M.A., is an assistant professor at Utsunomiya University. She teaches first year EFL classes. Her primary research interests are intercultural communication and second language identity. <minei@cc.utsunomiya-u.ac.jp>

Chieko Mimura, Ed.D., is Professor/Coordinator of the English Program of Utsunomiya University, which is the academic literacy EFL program. Her research interests include language and identity, curriculum development, and critical pedagogy.<chiekomimura@ cc.utsunomiya-u.ac.jp> 


\section{JALT2020}

COMMUNITIES OF
TEACHERS \& IEARNERS

Mine \& Mimura: Raising Cultural Awareness in EFL Classes

\section{References}

Arabski, J., \& Wojtaszek, A. (2013). Aspects of culture in second language acquisition and foreign language learning. Springer Berlin. http://dx.doi.org/10.1007/978-3-642-20201-8

Atkinson, D. (1999). TESOL and culture. TESOL Quarterly, 33, 625-654. https://doi. org/10.2307/3587880

Aufa, F. (2013). Stereotyping in the classroom: Promoting intercultural communicative competence in English language teaching. Lingua Didaktika: Jurnal Bahasa and Pembelajaran Bahasa, 7(1), 9-16. https://doi.org/10.24036/ld.v7i1.7254

Baker, W. (2012). From cultural awareness to intercultural awareness: Culture in ELT. ELT Journal, 66(1), 62-70. http://dx.doi.org/10.1093/elt/ccr017

Baker, W. (2017). Culture and identity through English as a lingua franca. De Gruyter. https://doi. org/10.1515/9781501502149

Byrum, M. (1997). Teaching and assessing intercultural communicative competence. Multilingual Matters. http://dx.doi.org/10.21832/BYRAM0244

Council of Europe. (2001). Common European framework of reference for languages: Learning teaching, assessment. Cambridge University Press.

Deardorff, D. K., \& Arasarantnam-Smith, L. A. (2017). Intercultural competence in higher education. Routledge. http://dx.doi.org/10.4324/9781315529257

Gee, J. (1993). An introduction to human languages: Fundamental concepts in linguistics. Prentice Hall.

Hall, S. (1997). The spectacle of the "other." In S. Hall (Ed.), Representation: Cultural representations and signifying practices (pp. 22-29). Sage/Open University.

Hesar, M. P., Konka, M. Y., \& Zarfsaz, E. (2012). Why and how to apply culture in an EFL classroom? 2012 International Conference on Language, Medias and Culture IPEDR, 33, 68-72.

Hofstede, G. (2011). Dimensionalizing cultures: The Hofstede model in context. Online Readings in Psychology and Culture, 2(1). http://dx.doi.org/10.9707/2307-0919.1014

Kachru, B. B. (1989). Teaching world Englishes. Indian Journal of Applied Linguistics, 15(1): 85-95. Kramsch, C. (1998). Language and culture. Oxford University Press.

Kumaravadivelu, B. (2008). Cultural globalization and language education. Yale University Press.

Lopez-Rocha, S. (2016). Intercultural communicative competence: Creating awareness and promoting skills in the language classroom. In C. Goria, O. Speicher, \& S. Stollhans (Eds.), Innovative language teaching and learning at university: Enhancing participation and collaboration (pp. 105-111). Research-publishing.net. http://dx.doi.org/10.14705/rpnet.2016.000411

McKay, S. L. (2002). Teaching English as an international language. Oxford University Press.
Matsumoto, K. (2013). An attempt to construct the objectives of intercultural communicative competence and its instructional models. 文明[Culture], 18, 51-63.

Matsuura, Y., Miyazaki, R., \& Fukushima, S. (2012). A case study of Hungary's development of education for intercultural communicative competence: The design of Japanese language teaching materials. 国際交流基金日本語教育紀要 Uournal of the Japan Foundation JapaneseLanguage Education], 8, 87-101.

MEXT. (2018). 高等学校学習指導要領解説 外国語編-英語編 [Explanation of high school course of study in foreign language: in English]. Retrieved from http://ssk.econfn.com/kougi/koukosidou. pdf

Ottoson, K. (2016). Self-assessment of intercultural communicative competence. In P. Clements, A. Krause, \& H. Brown (Eds.), Focus on the learner (pp. 499-505). JALT. Retrieved from jalt2015pcp_065.pdf (jalt-publications.org)

Skopinskaya, L. (2009). Assessing intercultural communicative competence: Test construction issues. Synergies Pays Riverains de la Baltique, 6, 135-144.

Ting-Toomey, S., \& Chung, L. C. (2011). Understanding intercultural communication. Oxford University.

Tomlinson, J. (1999). Globalization and culture. Polity. http://dx.doi.org/10.1007/978-1-137-28787846

Williams, R. (1976). Keywords: A vocabulary of culture and society. Oxford University Press. 


\section{JALT2020} COMMUNITIES OF
TEACHERS \& LEARNERS

\section{Reading Materials}

\section{Appendix A}

These are the teacher-generated materials that were written by the authors and their colleagues.

\section{1) High-Context and Low-Context Communication}

\section{Makito's Story}

Having been raised in the U.S., l'm used to a direct style of communication. I value and prefer clarity when communicating with people. So, when I came back to live in Japan, I found myself struggling to understand my colleagues and superiors because they often communicated in an indirect, round-about manner.

A good example of this difference in communication styles can be seen in how superiors assign tasks. In the U.S., they usually give clear instructions specifying what to do, who to work with, and when to do it by. They make sure that their team members know exactly what to do in order to accomplish a particular goal. In Japan, however, they say things like 〜してもいいかもしれ ない and 〜までにしておくといいかもね. At first, I used to think that these were just suggestions. I thought that they were just giving me some advice, so sometimes I listened and sometimes I didn't. Therefore, when my superior reprimanded me one day for not having even started on a task I was supposedly assigned, I was completely dumbfounded. I had no idea that I had been assigned this task. That day, I realized that this cultural difference in communication style was causing a lot of the struggles that $\mathrm{I}$ had been experiencing since returning to Japan.

I still struggle with it today, but now that I'm aware of this difference, I hope l've improved at least a little in understanding indirect communication.
2) Individualism and Collectivism

Yoko's Story

If you observe a conventional classroom both in Japan and America, you will soon find a difference in teacherstudent and student-student interactions.

I was born and raised in Fukushima, Japan. Up until I finished my junior college, I was educated in Japan. I went to both public and private schools, and there were approximately twenty-five to thirty students in every class. During class, when the teacher was talking, students usually remained silent. They listened to their teacher (some pretended?), and no one really spoke up. If students had questions, they asked their teacher individually after class. If you graduated from schools in Japan, you may relate to my story.

Later, I moved to Hawaii and went to an American university. I took four classes in the first semester. They were small classes with twenty to thirty students, just like the class size I had in Japan. But the way teachers and students interacted with each other in class was totally different from what I had known. Students freely jumped in and spoke up even while their teacher was talking to the whole class. Students would actively ask questions, and even give comments to their teacher and to their classmates.

I believe that the culture we live in affects students' attitudes as well. There are probably a number of reasons why many students in Japan sit quietly in class. Each student has their own reason. However, I assume a common factor would be our culture that values selflessness. Students harmonize with each other by being the same with other students. On the other hand, in America, which I think values more independency, many students freely express themselves.

\section{3) Stereotypes}

Inochi's Story

When I was studying at a graduate school, our teacher assigned us a group project, and we had to write a research paper together. My group had two non-native speakers of English, a native speaker of English, and myself. We divided the work by assigning ourselves different tasks: Esther and Jen, the non-native students, and I were to write a paragraph each, and Katie, the native student, took on the role of editing and writing up the conclusion.

Esther and I sent our paragraphs to Katie, and Jen was yet to send hers. A few hours later, however, Katie wrote on our group messenger, "Hey guys, I finished editing and wrote the conclusion." Jen immediately responded, "Wait! I haven't sent my part yet!" The problem was that Katie went ahead and wrote the conclusion without receiving Jen's part. What made the situation even worse was that Katie became unresponsive to our messages thereafter (maybe she was off to vacation thinking her job was done!). Jen sent Katie her paragraph soon after, but there was no response. As a last resort, Jen rewrote the whole conclusion.

What was surprising to me was that the conclusion paragraph Jen wrote was far better than what Katie had written. In every aspect (grammar, content, organization, etc.), Jen's writing was of much higher quality than Katie's.

This experience made me realize my stereotype about native speakers and non-native speakers. At the start of our group project, I was thinking that Katie would be the best editor and writer for our group. On the contrary, though, Jen - the non-native student-proved herself a much better writer, and a more diligent and reliable student. 
JALT2020

COMMUNITIES OF
TEACHERS \& LEARNERS

\section{4) Non-Verbal Communication}

\section{Joel's Story}

During the summer between my first and second years of university, I was lucky enough to do a student exchange program in Italy. For a month, I studied the Italian language, traveled around the country, and took in as much of the culture as I could. It was amazing. But there was one thing that was difficult to get used to.

Growing up in the U.S., I thought boys were not very physically affectionate with other boys. We didn't hug each other and we certainly never kissed each other's cheeks! But, in Italy, I often saw men exchange "air kisses" - that is, kissing each cheek in succession, left, right, and sometimes left again - with close friends and family members. This seemed very strange to me.

Over the course of my stay in Italy, I became very friendly with the night watchman in our dormitory. I often could not sleep well and so would leave my room to go watch late-night TV programs with Ezio. We talked about soccer and food and my experiences traveling in Italy. Those late-night chats with Ezio are some of my fondest memories of my time in Assissi.

When it came time to return to the U.S., I made sure to say goodbye to my friend Ezio, who promptly took my face in both hands and gave me big, wet kisses on both cheeks. I didn't know how to react! Finally, not knowing what else to do, I wrapped Ezio up in a big bear hug, mumbled, "grazie di tutto," or, thanks for everything, and ran for my bus.

I'm much more comfortable with different people's behavior these days and I consider myself lucky to have friends from many different backgrounds, but I still remember the feeling of shock I had and I try to be patient when other people's behaviors are different from my own.

\section{5) Ethnocentrism}

\section{Irene's Story}

When I first moved to the U.S. for college, I found many things "strange" about the people. First thing I noticed was the way people dressed. Many college students were wearing workout clothes such as running shorts, yoga pants, t-shirts, and tennis shoes or flip-flops although they were not necessarily going to work out! I couldn't understand why. I also noticed that people tend to talk loudly regardless of the surroundings. I thought they had no manners.

After living in the U.S. for a few years, however, I find it quite comfortable to be in workout clothes and understand why people wear these types of clothes often especially during school days. Also, I learned that each language has its own frequency, and Japanese and English have totally different frequencies that it requires us to talk loudly when talking in English for everyone else to hear us clearly.

Without realizing, I was evaluating the people of culture according to my standards and was looking down on it. We all tend to think that our own value and commonsense are the way of life but I learned that it is not actually the case. I thought we all should not be quick to judge, and remember that each culture has its own values and standards but there is no such superiority or inferiority between them.
6) Power Distance

\section{Chieko's Story}

Let me tell you three episodes that still makes me wonder what I should do.

When I was a student in an American university, I was so surprised that one of my American classmates called our professor by her first name, May. What! Dr. Chou was my dear professor who I respect so much. I would never have called her May. Most of my classmates called her Dr, Chou, but some American white male students called her by her first name. I was also shocked to see Dr. Chou look a little friendlier to them rather than to us. (Us...maybe Asian students. By the way, Dr. Chou was Chinese American.) Some professors in the university told the students to call them by their first names, but even when they were called by their last names, the professors did not correct the students. So, I realized that both first names and last names were fine. However, I could never call them by their first names myself because I thought it would be too rude.

In another university, I had an academic advisor, who was a renowned professor. In my first email to him, I started with "Dear Dr. Watkinson." Dr. Watkinson wrote me back, "The first assignment for you is to call me David." Wow! How nice he is! I was hesitant, but all other students called him David, so I started to feel rather awkward to call him Dr. Watkinson. Then he became "David." My respect to him did not change at all even though I called him David.

Then I met this teacher at a professional training school. His name was John Quan, and he was from Hawaii. He told us in class that he was frustrated when he was called John. He said, "There's no respect there. I don't like that." So we called him Dr. Quan.

My personal conclusion is that maybe it would not be a good idea to call native-speaker professors by their first names from the beginning. We should call Professor or Doctor first, then see what happens. 


\section{JALT2020}

COMMUNITIES OF
TEACHERS \& IEARNERS

\section{Reading Prompts}

English translations were done by the authors, and they were included in the original Reading Prompts.

1. このストーリーから解釈できることをなんでも書いてください。Write anything that you could interpret from this story.

2. このストーリーはどのように自分と関連づけられますか? How does this story relate to you?

3. このストーリーを通して何を学びましたか? What did you learn from this story?

\section{Questionnaire}

\section{Appendix C}

English translations were done by the authors, but they were not included in the original questionnaire.

1. 異文化コミュニケーションに対しての関心に変化はありましたか? Did your interests for intercultural communication change?

2.「「った」と答えた方は、どのような変化がありましたか? If you answered “yes,” what kind of changes did you experience?

3. この 2 回の授業を通して一番学んだことはなんですか? What did you learn the most through these 2 classes?

4. 他の言語を母国語とする方々との関わり方で何か考えることがあれば書いてください。If you have anything that you think about interacting with people who speak other languages as their first language, please write them down

\section{Appendix D}

Main Questions Asked in the Interviews

English translations were done by the authors, but the interviews were all done in Japanese.

1. 読んだストーリーの中で一番心に残っているストーリーはどれですか。またそれはなぜ心に 残ったと思いますか。Which story do you remember the most? Why do you think the story was memorable for you?

2. カルチャーの授業で何かを考えたことで覚えていることはありますか。Do you remember anything that you thought about the stories during the classes?
3. 授業を通して学んだことから実践していること・意識していることはありますか Are there anything that you are practicing or being mindful of from the things that you learned in the classes?

4. ストーリ一を読んで、筆者の解釈と自分の解釈は違うなと思った部分はありますか。違和感を 感じたことを覚えていたら教えてください。Was there anything that you think you would interpret the intercultural communication situation differently from the writer of the stories? Please tell us if you had any discomfort reading the stories.

5. 今までの異文化の経験について教えてください。Please tell us about your previous intercultural experiences.

6. 今後異文化の方とどのようなつながりを持ちたいですか。What kind of relationships do you want to have with people of other cultures?

7. 次にこのようなカルチャーの授業があったら、どんなことをしたいですか。What kind of things do you want to do if there is going to be a culture class in the future?

\section{Appendix E}

Comments from the Students

These following comments were translated by the authors.

1. Reading Prompts

a. Stereotypical comments from the students

- Japanese people tend to make more ambiguous statements than people from other countries.

- American students have an active attitude toward classes, while Japanese students have a passive attitude.

- In Italy, physical contact is often used when people communicate.

- U.S. students wear workout clothes and talk loudly.

b. Comments from students reflecting other interpretations of the stories

- Japanese and Americans think differently about hierarchical relationships (Story of high- and low-context communication).

- I think it depends not on the country, but on the teacher's way of teaching. When students in Japan ask questions in class, most teachers will tell them to save their 
questions for later, after class. So, students internalize the message that they shouldn't ask questions in class (Story of individualism vs. collectivism).

- Most difficulties can be overcome through diligence and effort (Story of stereotypes).

- Judgments based on established stereotypes can lead to failure (Story of stereotypes).

- Roles should be assigned appropriately (Story of stereotypes)

- It's easier to live without worrying about what people think of you (Story of ethnocentrism).

\section{Class Reflection}

- When communicating with people from different cultures or using different languages, I understand the importance of keeping the differences in mind. Any prejudices I have are my own loss. We often swayed by prejudices without recognizing them. I want to look for the good points in others every day. People cooperate better when they recognize each other's good points and capabilities.

- 1 knew that cultural differences between countries inevitably appear in classrooms and in communication but hadn't experienced any myself. It was interesting to hear other people's experiences.

- We think about cultural differences between us and other countries, but there are differences within Japan, as well. I'm going to keep this in mind here at Utsunomiya University, where people from different parts of Japan come together

- Before, the sight of foreigners talking loudly scared me a little. I thought they had bad manners. Now I realize that their cultures aren't inferior, just different from our culture. I regret my ignorant thoughts in the past.

- Silence in the classroom and roundabout styles of communication are familiar to me as a Japanese. I remember seeing an ALT teacher struggle to generate energy in a classroom of passive students. I recognized that an inactive attitude can be a weak point. The stories this time got me to thinking again about the national character of the Japanese.

\section{Overall Reflection}

- The values people hold are shaped by the environments in which they grow up. Every country has its good parts. It is important to understand every country's values, ideas, and customs.

- I thought that cultural differences are seen in smaller parts than what I had expected. I think it will be hard to really know the differences until I experience them first-hand.

- In order to understand different cultures, I must be able to think from a wider range of perspectives.

- I used to think I was never prejudiced against anyone. Hearing the stories, I came to recognize that I have more prejudices than I knew.

\section{Interview}

a. Students who had little or no previous intercultural experience

- I have been learning English to prepare for my exams. I never had the idea of connecting English with culture. I sometimes find it difficult when I try to translate Japanese into English. Now I recognize that it might be easier if I understand more about other cultures.

- Even if there are people who hold different opinions or act differently from me, the class showed me that it can be better to think from a wider perspective, moving outside of my own values.

- I came to realize that I can't really know a person before talking to them one to one. In other words, I became less prejudiced.

b. Students who had some previous intercultural experience

- The stories sounded familiar to me. I have had the same experiences in my studyabroad and exchange programs.

- I had the impression that the stories were comparing Japan and countries overseas. If you read these stories, you will think things are better overseas. They seem to be about one being superior and the other being inferior. I don't think that's good. People could be in denial of their experience in Japan and lose confidence. It's okay to have confidence as a Japanese. 